\title{
INVESTIGAÇÃO DE LIPOFUSCINA EM MIÓCITOS CARDÍACOS DE CAMUNDONGOS APÓS TRATAMENTO COM OXAMNIQUINE [*]
}

\author{
Maria Luiza Silveira MELLo (1) e Carmen S. BERTUZzo (2)
}

\begin{abstract}
RES U M O
A fluorescência natural devida à presença de corpos de lipofuscina foi pesquisada em miócitos cardíacos de camundongos adultos jovens tratados com oxamniquine. O objetivo foi buscar uma evidência de indução de envelhecimento celular precoce, com base em dados prévios de acentuação poliploidia, promovida pela droga. Comparando o miocárdio dos camundongos tratados com animais contrôle jcvens e velhos, não foi observada a presença de lipofuscina nos seus miócitos. Isto possivelmente se deva a um não comprometimento da eficiência das lipases lisossomiais apesar da acentuação do fenômeno de poliploidização induzida pela droga.
\end{abstract}

\section{N T R O D U G A $\mathbf{A}$}

A oxamniquine, droga utilizada no tratamento da esquistossomose desde 1969 , não provoca aberrações cromossômicas em pacientes portadores da doença ${ }^{6}$. Também não foram reportadas alterações moleculares ao nível do DNA em células de animais tratados com tal ăroga 2. No entanto, há indicações de que a oxamniquine possa acentuar a poliploidia em alguns núcleos da musculatura cardíaca de camundongos adultos jovens, o que talvez pudesse ser acarretado pela promoção de um envelhecimento celular precoce ${ }^{1}$.

E fato conhecido, por outro lado, de que, com o envelhecimento, há acúmulo de corpos residuais com lipofuscina em miócitos cardía$\cos ^{3}$. No presente trabalho busca-se, portanto, investigar se o tratamento com oxamniquine induz em animais adultos jovens sadios um envelhecimento acelerado nessas células, medido pela presença de corpos de lipofuscina.

\section{MATERIAL E METODOS}

Dez camundongos com 3 meses de idade receberam uma dose oral de $0,436 \mathrm{mg}$ de oxamniquine por $\mathrm{g}$ de peso corpóreo. A dose eficaz $\left(\mathrm{DE}_{99}\right)$ oral desta droga em camundongos é de $44 \mathrm{mg} / \mathrm{kg}$ e a letal $\left(\mathrm{DL}_{50}\right)$ oral, $1300 \mathrm{mg} / \mathrm{kg} 4$. Como controles foram utilizados três animais com 3 meses e três com 2 anos, os quais receberam $0,31 \mathrm{ml}$ de água.

Trinta dias após a administração da droga foram obtidos preparados dos miocárdios, onde se pesquisou a fluorescência natural devida à presença de lipofuscina ${ }^{5}$. Pequenos fragmentos do músculo cardíaco foram cortados em micrótomo de congelação, montados em gelatina-glicerina e examinados num fotomicroscópio Zeiss equipado para fluorescência.

\section{RESULTADOS E DISGUSSÃO}

A fluorescência natural devida a corpos de lipofuscina foi constatada apenas nos miócitos dos animais velhos não tratados com a droga.

(*) Trabalho realizado no Departamento de Biologia Celular, Instituto de Biologia, UNICAMP, 13100 Campinas (SP), Brazil

(1) Professor Titular

(2) Estagiária 
MELLO, M. L. S. \& BERTUZZO, C. S. - Investigação de lipofuscina em miócitos cardíacos de camunđongos após tra. tamento com oxamniquine. Rev. Inst. Med. trop. São Paulo 26:241-242, 1984.

Portanto, se a poliploidia acentuada pela oxamniquine, conforme descrição prévia 1, está associada a um envelhecimento celular precoce, este pelo menos não se reflete no aparecimento generalizado de corpos residuais com lipofuscina detectáveis à microscopia de Iuz. Talvez, então, a acentuação da poliploidização no miocárdio com a ação da droga não seja acompanhada por um decréscimo na atividade lisossomial referente à eficiência de lipases ${ }^{3}$.

Deste modo não ocorreria um acúmulo significante de lipofuscina, como o de células musculares poliplóides de indivíduos velhos ${ }^{3}$.

\section{SUIMMARY}

\section{Investigation of lipofuscin in cardiac miocytes of mice treated with oxamniquine}

The autofluorescence due to lipofuscin bodies was investigated in cardiac miocytes of young adult mice treated with oxamniquine. The aim was to detect evidence for a cell aging process promoted by the drug, taking into account previous findings on the enhancement of polyploidy in this material. However, as no lipofuscin was observed in these cells, when compared to young and old control ani- mals, it is assumed that the efficiency of the lysosome lipases in the heart miocytes of the treated mice is not affected by the drug induced polyploidy enhancement.

\section{REFERENCIAS BIBLIOGRAFICAS}

1. BECHARA, I. J.; CORDEIRO, J. A. \& MELLO, M. L. S. - Alteração na frequiência de tipos nucleares em músculo cardíaco de camundongo induzida por oxamniquine. Ciênc. Cult. 34: 1191-1195, 1982.

2. BECHARA, I. J. \& MELLO, M. L. S. - Basofilia e anisotropia nucleares em células de camundongos após tratamento com oxamniquine. Rev. Inst. Med. trop. São Paulo 26: 31-37, 1984.

3. BRANDES, D. - Lysosomes andl aging pigment. In Topics in the Biology of Aging (P. L. Krrohn, ed.). New York, John Wiley \& Sons, 1966, 149-158.

4. FOSTER, R. - The preclinical development of oxamni. quine. Rev. Inst. Med. trop. São Paulo 6: $1-9,1973$.

5. LISON, L. - Histochimie et Cytochimie Animales. Paris, Gauthier-Villars, 1960.

6. MONSALVE, M. V.; PESSOA, O. F.; CAMPOS, A. M G. \& SETTE, H. - A study of chromosomes of schistosomiasis patients under oxamniquine (UK 4271) treat. ment. J. Toxicol. Envir. Health 1: 1023-1025, 1976.

Recebiđo para publicação em 29/9/1983. 